Muslims Venture into Politics in India: A British Ploy or an Instinctive Reaction

\title{
MUSLIMS VENTURE INTO POLITICS IN COLONIAL INDIA: A BRITISH PLOY OR AN INSTINCTIVE REACTION? ${ }^{1}$
}

\author{
Belkacem BELMEKKI \\ University of Oran 2 Mohamed Ben Ahmed, Oran, Algeria \\ Laboratoire de Langues, Littérature et Civilisation/Histoire en Afrique \\ belkacem.belmekki@univ-oran2.dz
}

The formation of the All-India Muslim League, the first ever Muslim political party in British India to see the light of the day, represents a watershed in the political history of the Indian subcontinent. It was, in fact, the outcome of a long historical process during which the Muslims of India faced challenges at different levels, political, economic and socio-cultural. Yet, the origin of this political organisation has been a moot point among scholars. Did the British have a hand in its creation or was it a genuinely Muslim initiative? The aim of this article, therefore, is to investigate this issue as well as shed light on the circumstances that led to the birth of this party.

Keywords : All-India Muslim League, Indian National Congress, Sir Sayyid Ahmad Khan, Aligarh Movement, Hindus, Indian Muslims

From the time of English East India Company rule in the Indian subcontinent by the second half of the eighteenth century and the removal of the Mughals from the position of power that took place subsequently, Indian Muslims entered a new chapter in their history, often qualified by scholars and contemporaries as a dark chapter, during which this community kept a low profile and, politically, went into hibernation. In fact, apart from some revivalist movements, which were more religious than political in character, such as the one led by the theologian Shah Walyi Allah Delhavi², Muslim involvement in politics was

\footnotetext{
${ }^{1}$ I would like to thank the Algerian Directorate General for Scientific Research and Technological Development (DGRSDT) for having funded my research.

2 For more information about this topic, see BELMEKKI, B. Shah Walyi Allah Delhavi's Attempts at Religious Revivalism in South Asia. In Anthropos: International Review of Anthropology and Linguistics, 2014, Vol. 109, No. 2, pp. 621-625.
} 
almost inexistent. In fact, even when the first major political party on an allIndia basis, the Indian National Congress, was founded in 1885, very few Muslim figures joined it and the overwhelming majority remained aloof from any such organizations. In this regard, it is significant to note that Indian Muslims on the whole gave politics a wide berth, following the advice of the nineteenth-century community reformer, Sir Sayyid Ahmad Khan ${ }^{3}$, who, through his movement, the Aligarh Movement ${ }^{4}$, strove to keep his coreligionists away from politics.

It is noteworthy to mention in passing that this decision on the part of this Muslim leader was motivated by various reasons, which were mostly religious and political. The aim in this article, however, is not to deal with this aspect, but for the sake of clarification it is deemed necessary to sketch out briefly the most important ones.

First, basing his argument on religious grounds, Sir Sayyid Ahmad Khan urged his co-religionists to adopt a pro-British attitude because, as Christians, the British were closer to the Indian Muslims, given the fact that Christianity was closer to Islam than any other religion - including Hinduism -, both being monotheistic, Abrahamic religions that stemmed from the same source. This made him highlight on every occasion the resemblance of, in the words of Percival Spear, "fundamental Islamic and Christian ideas with their common Judaic heritage."5 Furthermore, Sir Sayyid Ahmad Khan reminded the Muslims of India about the fact that:

No religion upon earth was more friendly to Christianity than Islam; and the latter had been more beneficial and advantageous to Christianity ... Islam fought against Judaism in favour of Christianity, and openly and

\footnotetext{
3 Sir Sayyid Ahmad Khan (1817 - 1898) was a prominent Muslim intellectual, educationist and reformer in nineteenth century British India.

${ }^{4}$ The Aligarh Movement was founded by Sir Sayyid Ahmad Khan in the wake of the bloody events of 1857. It was a vigorous movement, which was liberal and modernist in character, with the aim of reforming the Muslim community in British India. Aligarh is a city in the north of India in what is today the state of Uttar Pradesh.

${ }^{5}$ SPEAR, P. A History of India: From the Sixteenth Century to the Twentieth Century, p. 225. In 1862, Sir Sayyid Ahmad wrote a book entitled Tabiyn al-Kalam Fi Tafsir alTawrat wa al-Injyl Ala Millat al-Islam (The Mahomedan Commentary on the Holy Bible), the first book of its kind to be written by a Muslim intellectual in the subcontinent, in which he demonstrated by delineating their similarities that Islam and Christianity had never been opposed to each other. MALIK, H. Sir Sayyid Ahmad Khan and Muslim Modernization in India and Pakistan, pp. 83-84.
} 
Muslims Venture into Politics in India: A British Ploy or an Instinctive Reaction

manfully did it declare that the mission of ... Jesus Christ was unquestionably 'the Word of God' and 'the Spirit of God. ${ }^{6}$

In the meantime, politically, Sir Sayyid Ahmad Khan's pro-British stance was motivated by his fear of and lack of trust in the Hindu majority. As a matter of fact, he gave much thought to the contemporary context in late nineteenthcentury British India and came to the conclusion that the Muslims of India were in a much-enfeebled position, especially after the fateful events of 1857 , and that unless they pledged allegiance to the new masters in the subcontinent, namely the British, their already pitiable conditions would get even worse. In other words, as a minority, the Indian Muslims were constrained to seek refuge with the new rulers by befriending them and any involvement in politics would antagonize them. Therefore, it was not in the interest of the 'Mohammedans' as they were often referred to by western scholars at the time - to incur the displeasure of the British especially since relations with the Hindu majority were not always smooth. Corroborating this idea, Khursheed Aziz observed:

Sayyid Ahmad Khan foresaw that the Muslim minority was no match for the progressive Hindus and that if it also alienated the sympathies of the rulers its ruin would be complete. ${ }^{7}$

In a nutshell, according to Sir Sayyid Ahmad Khan, it would be a wise decision for the Muslims to cast their lot with the British, the new masters, especially in that all the circumstances in the subcontinent indicated that they i.e. the British - would not cease to be the masters in India, at least in the foreseeable future. ${ }^{8}$ Hence, aloofness from politics was a necessity and siding with the British was a matter of survival as the latter "were responsible for distributing the limited quantity of 'loaves and fishes' available". 9 Summing up this situation, Muhammad Y. Abbasi affirmed that in the view of Sir Sayyid Ahmad Khan, avoiding politics and adopting a loyal attitude to the rulers of the day was not a mere policy of opportunism, but also the dictate of political realism. $^{10}$

Nevertheless, a wind of change started blowing across the subcontinent by the late nineteenth century and early twentieth century that made Muslims

\footnotetext{
${ }^{6}$ Quoted in SHAN, M. (ed.). The Aligarh Movement: Basic Documents: 1864 - 1898, pp. xi-xii.

${ }^{7}$ AZIZ, K. K., The Making of Pakistan: A Study in Nationalism, p. 70.

${ }^{8}$ Ibid., p. 19.

${ }^{9}$ MASSELOS, J. Indian Nationalism: An History, p. 120.

${ }^{10}$ ABBASI, M. Y. The Genesis of Muslim Fundamentalism in British India, p. 14.
} 
reconsider their political disengagement on the Indian scene. In fact, two key factors were to serve as a catalyst that prompted Indian Muslims to stray away from Sir Sayyid Ahamd Khan's advice and venture into politics: the prospects of new colonial reforms and the Hindu 'overreaction' to the partition of Bengal.

Regarding the former, it was the passing of the Indian Councils Act of 1892 that set the alarm bell ringing among the Muslim community in that it was seen as a clear sign that the colonial administration was moving towards a form of representative government. Actually, this Act, which came in response to a great deal of pressure exerted by Indian nationalists, increased the powers of the Legislative Council as well as the number of representatives. ${ }^{11}$ While this measure was applauded by the Congressmen (i.e. the members of the Indian National Congress) and was seen as a milestone in their political struggle, the Indian Muslims, however, construed it as a serious threat to their separate interests, given their small number compared to the Hindu majority. In other words, numerically speaking, the Hindus were four times the size of the Muslims, and hence, in a democratic context marked by a one-man one-vote system, there would be four Hindu votes for every one Muslim vote. ${ }^{12}$ This meant that every move towards democracy was tantamount to the oppression of the Muslim minority by the Hindu majority, or so the thinking among the Muslims at the time went. Commenting on this situation, Percival Spear wrote: "A democratic regime means majority rule, and majority rule in India would mean Hindu rule.",13

Consequently, faced with such a significant challenge, brought about by the political mutations that were taking place on the Indian stage, Indian Muslims grew more distrustful of the atmosphere in the country and found themselves more than ever in a new context, one marked by insecurity and vulnerability. Eventually this state of mind was going to prove instrumental in impelling the leaders of the Muslim community to change their mind regarding aloofness from politics. Describing the conditions of the time, Khursheed K. Aziz wrote:

Seeds of representative institutions, sown by the Indian Councils Act of 1892 , might at any moment sprout into more far-reaching reforms. It was

11 For instance, thanks to the Indian Councils Act of 1892, the members of the Legislative Councils would be able to discuss, for the first time, matters related to the annual budget. HORNE, E. A. The Political System of British India: With Special Reference to the Recent Constitutional Changes, p. 59.

12 MEHROTRA, S. R. India and the Commonwealth: 1885 - 1929, p. 179.

${ }^{13}$ SPEAR, P. A History of India: From the Sixteenth Century to the Twentieth Century, p. 226. 
Muslims Venture into Politics in India: A British Ploy or an Instinctive Reaction

unwise to depend entirely upon the good opinion of the rulers, though it was a cause of much gratification. ${ }^{14}$

On the other hand, the other catalyst - which probably had much more influence than the one just mentioned - that prompted Indian Muslims to enter politics was the Hindu 'overreaction' to the partition of Bengal decreed by the government of India in 1905. Some scholars go further in their evaluation of the impact of this event as being a very decisive factor that changed the course of the political history of British India. Vinod K. Saxena, for instance, referring to the eventful year of 1905, stated that "it would be no exaggeration to say that it was an epoch-making year, which left a profound impact on the political history of the country". ${ }^{15}$

The project of partitioning Bengal was proposed by the government of India during the viceroyalty of Lord Curzon (1859 - 1925). Curzon, seeing that Bengal was such a huge province that was difficult to administer, decided that it would be judicious and wise to divide it into two manageable provinces: Western Bengal, on the one hand, with a population of 54 million, of which 42 million were Hindus and only 9 million Muslims; and on the other hand, Eastern Bengal and Assam, with a population of 31 million, of which eighteen million were Muslims and twelve million Hindus. ${ }^{16}$

As can be inferred from the figures above, the direct outcome of this partition was the creation, for the first time in the subcontinent, of a Muslimmajority province. For obvious reasons, the overwhelming majority of Muslims hailed this division since, in a province where they represented the majority, they would have the upper hand and, therefore, their interests would be safeguarded. Naturally, this project brought a great deal of joy to many Muslim residents of the newly-born province who breathed a sigh of relief. ${ }^{17}$ Lending support to this statement, Shameem. H. Kadri quoted a contemporary as saying that under the new scheme, the Muslims "would be spared of (sic) many

\footnotetext{
${ }^{14}$ AZIZ, K. K. The Making of Pakistan: A Study in Nationalism, p. 23.

${ }^{15}$ SAXENA, V. K. Muslims and the Indian National Congress: 1885 - 1924, p. 109.

${ }^{16}$ SHAMEEM, H. K. Creation of Pakistan, p. 14. To justify his initiative, Lord Curzon declared: "What we want in India is personal knowledge of localities and personal touch with the people. This can only be gained by the familiarity of the Head of the Administration with the places and people under his charge." AZIZ, K. K. The Making of Pakistan: A Study in Nationalism, p. 24.

17 According to Tariq Hasan, this division was construed by a large section of the Muslim community as a token of gratitude from the British Government for their loyalism. HASAN, T. The Aligarh Movement and the Making of the Indian Muslim Mind: 1857 - 2002, p. 147.
} 
oppressions (sic) which they had hitherto had to endure from the Hindus". 18 . Also, reflecting the Muslims' satisfaction with the partition project, in one article from the Aligarh Institute Gazette of 13 June 1906, it was written:

The partition of Bengal will prove a Godsend blessing to the Musalman residents of that province, who will now find splendid opportunity for making rapid progress both in their education and social position. ${ }^{19}$

Meanwhile, on the other end of the spectrum, Lord Curzon's initiative made the Hindus raise their eyebrows as to the real motives behind such an endeavour. Indeed, many Hindu activists, deploring the "vivisection of the Bengali heartland" 20 as "preposterous", 21 were convinced that the partition of their province was, ostensibly, for administrative reasons but in reality it was nothing more than a stratagem whereby the British Governor General wanted to strike at the heart of the Indian nationalist movement, knowing that Bengal was the province that sheltered the bulk of Indian nationalists. ${ }^{22}$ Along the same line of thought, Bipan Chandra et al. claimed that Bengal was the bedrock, or the nerve centre, of the Indian nationalist movement at that time, ${ }^{23}$ and that the real objective behind this border reorganization in the province was to curb the "radical Bengali nationalists." 24

As expected, Lord Curzon's partition scheme triggered off a wave of protest throughout the country. These protests soon gained momentum, especially in the Bengal region, and took different forms. For instance, on the official day set for the implementation of Curzon's plan, 16 October 1905, Partition Day, many

\footnotetext{
${ }^{18}$ SHAMEEM, H. K. Creation of Pakistan, pp. 14-15.

19 SAXENA, V. K. Muslims and the Indian National Congress: 1885 - 1924, pp. 86-87.
}

${ }^{20}$ AZIZ, K. K. The Making of Pakistan: A Study in Nationalism, p. 25.

${ }^{21}$ CHANDRA, B., TRIPATHI, A., DE, B. Freedom Struggle, p. 85.

22 According to Sayed R. Wasti, Lord Curzon had little sympathy for the Indian National Congress. Referring to the latter, he once said that it was "tottering to its fall" and so he would "assist it to a peaceful demise". WASTI, S. R. Partition of Bengal and its Immediate Effects. In WASTI, S. R. (ed.). Muslim Struggle for Freedom in India, p. 67.

23 CHANDRA, B., MUKHERJEE, M., MUKHERJEE, A., PANIKKAR, K. N., MAHAJAN, S. India's Struggle for Immediate Independence, pp. 124-125. Comparing the Bengal province with other Indian provinces, Hans Kohn affirmed that it was the most advanced intellectually and the most conscious of its national and political individuality. KOHN, H. A History of Nationalism in the East, The Idea of Nationalism: Its Origin and Background p. 378.

${ }^{24}$ CHANDRA, B., TRIPATHI, A., DE, B. Freedom Struggle, p. 85. 
Hindus, already engaged in fierce anti-British agitation, observed a day of national mourning. ${ }^{25}$ In addition, a general hartal ${ }^{26}$ was organized on the same day, during which many people fasted - "no fires were lit at the cooking hearths" 27 - and walked barefooted towards the Ganga, the Hindu holy river, in order to take a bath as a ritual practice. ${ }^{28}$ Yet, interestingly enough, while on their way to the Ganga River, these Hindu activists were chanting patriotic songs such as Bande mataram. ${ }^{29}$ For the sake of clarity, it is worth noting that Bande mataram $^{30}$ was a Hindu revolutionary poem which invoked divine assistance against foreign intruders, namely the Muslims and the British, and which made it a duty on the members of the Hindu community to drive them both out of the Indian subcontinent. ${ }^{31}$ Hence, the anti-Partition agitation took on an anti-Muslim dimension. As confirmed by Vinod K. Saxena, who pointed out that Bande Mataram - which was made a sort of national anthem by the Congress leaders - appeared offensive to many Muslims because its verses were "taken to exalt Hinduism at the expense of Islam". ${ }^{32}$

Therefore, in the light of these recent developments on the Indian scene, namely the prospects of colonial reforms coupled with anti-partition Hindu agitation, the Muslims of India felt, for the first time after the downfall of the Mughal Empire, that they were "not only prepared but also anxious to take their full share in the political activities" as a separate and distinct community within India. ${ }^{33}$ Yet, before resorting to political action, some Muslim leaders attempted to negotiate with Hindu politicians to persuade them to see the communal realities and make their organization, i.e. the Indian National Congress, more attractive to their Muslim fellow countrymen. ${ }^{34}$ According to Khursheed K. Aziz, some prominent Muslim leaders had even remonstrated with Sir

\footnotetext{
${ }^{25}$ WASTI, S. R. Partition of Bengal and its Immediate Effects. In WASTI, S. R. (ed.). Muslim Struggle for Freedom in India, p. 69.

26 'Hartal' is a Hindi word meaning the suspension of business or work as a form of protest.

27 CHANDRA, B., MUKHERJEE, M., MUKHERJEE, A., PANIKKAR, K. N., MAHAJAN, S. India's Struggle for Immediate Independence, p. 127.

${ }^{28}$ CHANDRA, B., TRIPATHI, A., DE, B. Freedom Struggle, p. 87.

${ }^{29}$ Ibid.

${ }^{30}$ Bande mataram (literally meaning 'Hail to thee, Mother') was taken from Bankim Chaterjee's anti-Muslim novel entitled Anandamath. In READ, A., FISHER, D. The Proudest Day: India's Long Road to Independence, p. 91.

${ }^{31}$ AZIZ, K. K. The Making of Pakistan: A Study in Nationalism, p. 82.

${ }^{32}$ SAXENA, V. K. Muslims and the Indian National Congress: 1885 - 1924, p. 104.

${ }^{33}$ RAHMAN, M. From Consultation to Confrontation: A Study of the Muslim League in British Indian Politics: 1906 - 1912, p. 8.

${ }^{34}$ SHAMEEM, H. K. Creation of Pakistan, p. 17.
} 
Pherozeshah M. Mehta (1845 - 1915), a founding member of the Indian National Congress and president of its 1890 session, about the necessity of urging his Hindu partners to make some efforts to gain Muslim confidence. ${ }^{35}$ Nevertheless, all such efforts were to no avail.

As a result, the Muslim leaders of the Aligarh movement decided to approach the government of India in the most constitutional way. First, Nawab Mehdi Ali Khan, better known as Nawab Mohsin-ul-Mulk (1837 - 1907), one of the late Sir Sayyid Ahmad Khan's close associates, ${ }^{36}$ wrote in the name of his co-religionists a letter to William A. J. Archbold, ${ }^{37}$ who was leaving for Simla the summer capital of British India - for his holidays, asking him to request from the then Viceroy of India, Lord Minto, to receive a Muslim deputation. In this letter, which was sent on 4 August 1906, Mohsin-ul-Mulk explained to Archbold that the Muslim youth were getting restive as a result of the state of affairs in the subcontinent, and that if they remained silent, people "will leave us to go their own way and act up to their own personal opinions." 38 Then, Mohsin-ul-Mulk asked Archbold if it would be:

... advisable to submit a memorial from the Mohammedans to the Viceroy, and request His Excellency's permission for a deputation to wait on His Excellency to submit the views of Mohammedans on the matter. ${ }^{39}$

Hence, during his stay at Simla, which, in the opinion of Tariq Hasan, was more for business than pleasure, Archbold relayed the message to the colonial headquarters. ${ }^{40}$ Later on, after much discussion with the top officials, Archbold sent a telegram to Mohsin-ul-Mulk in which he stated that the Viceroy "agrees to receive a deputation of Muslims". 41

This took place on 1 October 1906, when a deputation, composed of thirtyfive Indian Muslims from all over India went to see the Viceroy, Lord Minto, at

\footnotetext{
${ }^{35}$ AZIZ, K. K. The Making of Pakistan: A Study in Nationalism, p. 29.

${ }^{36}$ Sir Sayyid Ahmad Khan passed away in 1898.

37 William A. J. Archbold was a British resident who served as the principal of the Muhammedan Anglo-Oriental College. The MAO College was founded in 1875 by Sir Sayyid Ahmad Khan as part of the efforts of the Aligarh Movement.

${ }^{38}$ Quoted in WASTI, S. R. The Simla Deputation: 1906. In WASTI, S. R. (ed.). Muslim Struggle for Freedom in India, p. 80.

${ }^{39}$ Ibid.

${ }^{40}$ HASAN, T. The Aligarh Movement and the Making of the Indian Muslim Mind: 1857 -2002 , p. 128.

${ }^{41}$ Ibid.
} 
his official summer residence in Simla. ${ }^{42}$ The members of this deputation which historically became known as the Simla Deputation - were largely drawn from the most influential members of the Muslim community in India. ${ }^{43}$ Syed R. Wasti claimed that though they were not chosen by their co-religionists to represent them, they "did command respect, popularity and considerable influence in their respective areas and represented many professions and various shades of opinion". ${ }^{44}$ Besides that, they were all connected with the Aligarh movement through the apolitical organization that the late Sir Sayyid Ahmad Khan helped set up in 1886, that is, the Muhammedan Educational Conference. $^{45}$

Prior to travelling to Simla, the deputation had already agreed on a memorandum to be presented to the Viceroy, which was drafted by Syed Husain Bilgrami, a former president of the Muhammedan Educational Conference, with the help of Nawab Mohsin-ul-Mulk - both staunch supporters of the late Sir Sayyid Ahmad Khan. ${ }^{46}$ According to Vinod K. Saxena, Nawab Mohsin-ul-Mulk was the one who "thought out the scheme of the Simla Deputation". 47

Heading such a Muslim delegation was a wealthy twenty-nine year old Indian Muslim from Bombay, Sultan Muhammad Shah Agha Khan (1877 1957), also a former president of the Muhammedan Educational Conference. ${ }^{48}$ Upon reaching Simla, the "Aligarh Group" were welcomed in the "afternoon's garden party at Viceregal Lodge". 49

42 READ, A., FISHER, D. The Proudest Day: India's Long Road to Independence, p. 91.

${ }^{43}$ Ibid.

${ }^{44}$ WASTI, S. R. The Simla Deputation: 1906. In WASTI, S. R. (ed.). Muslim Struggle for Freedom in India, p. 87.

${ }^{45}$ RAHMAN, M. From Consultation to Confrontation: A Study of the Muslim League in British Indian Politics: 1906 - 1912, p. 8. The Muhammedan Educational Conference (initially known as Muhammedan Educational Congress) was an auxiliary agency of the Aligarh Movement. Its objective was to help popularize Sir Sayyid Ahmad Khan's ideas and bring together the members of the Muslim community from outlying areas in the subcontinent; SHAN, M. (ed.). The Aligarh Movement: Basic Documents: 1864 - 1898, p. xxii.

${ }^{46}$ HASAN, T. The Aligarh Movement and the Making of the Indian Muslim Mind: 1857 -2002 , p. 129.

${ }^{47}$ SAXENA, V. K. Muslims and the Indian National Congress: 1885 - 1924, p. 84.

${ }^{48}$ RAHMAN, M. From Consultation to Confrontation: A Study of the Muslim League in British Indian Politics: 1906 - 1912, p. 9.

${ }^{49}$ WASTI, S. R. Lord Minto and the Indian Nationalist Movement: 1905 - 1910, p. 70. 
The memorandum that the deputationists were to present to Lord Minto, which was signed by $1,461,183$ Indian Muslims throughout India, ${ }^{50}$ was considered to be the first comprehensive document embodying Muslim aspirations in modern India. ${ }^{51}$ Describing this memorandum, Syed R. Wasti observed that it was written in the most moderate tone and, besides, it gave the impression that the deputationists were "politicians by compulsion rather than by choice," who were compelled by the prevailing circumstances in the subcontinent to come forward and voice their worries concerning the future position of their co-religionists in the light of the imminent wind of administrative change. ${ }^{52}$

The contents of the address dealt in the main with the need for special protection for the Muslims of India if representative government were to be extended, as well as asking for separate electorates through which the Indian Muslims should elect their own representatives in the local, provincial and central Legislative Councils. ${ }^{53}$ Put simply, the deputationists asked the Viceroy for an adequate representation in the Imperial Legislative Council and other councils, and demanded that Muslim representation should not be commensurate with their numerical strength but rather with their "political importance" in the country, ${ }^{54}$ as well as the value of the contribution which they made to the army and the defence of the Empire. ${ }^{55}$

The deputationists's address to the Viceroy - "inscribed in vellum" - was presented - "with exquisite courtesy"56 - in a methodical way. First, it began with complimenting the British rulers for the "peace, security, personal freedom, and the liberty of worship" that they had brought to the subcontinent. ${ }^{57}$ Then they criticized, in a polite way, the system of individual enfranchisement, viz. the one-man-one-vote system, and sought to draw the attention of the

\footnotetext{
${ }^{50}$ RAHMAN, M. From Consultation to Confrontation: A Study of the Muslim League in British Indian Politics: 1906 - 1912, pp. 8-9.

${ }^{51}$ HASAN, T. The Aligarh Movement and the Making of the Indian Muslim Mind: 1857 - 2002, p. 129.

${ }^{52}$ WASTI, S. R. The Simla Deputation: 1906. In WASTI, S. R. (ed.). Muslim Struggle for Freedom in India, p. 88.

${ }^{53}$ SYMONDS, R. The Making of Pakistan, pp. 40-41.

${ }^{54}$ HASAN, T. The Aligarh Movement and the Making of the Indian Muslim Mind: 1857 - 2002, p. 129.

55 RAHMAN, M. From Consultation to Confrontation: A Study of the Muslim League in British Indian Politics: 1906 - 1912, p. 12.

56 READ, A., FISHER, D. The Proudest Day: India's Long Road to Independence, p. 92.

${ }^{57}$ WASTI, S. R. The Simla Deputation: 1906. In WASTI, S. R. (ed.). Muslim Struggle for Freedom in India, p. 88.
} 
Viceroy to the fact that Muslim interests could by no means be safeguarded under a "European system of open election". ${ }^{58}$

Besides that, they also complained about the monopoly of official influence by one class - insinuating the Hindu community - pointing out that "no Muhammadan Judge sat in any Supreme Court". ${ }^{59}$ This point is dealt with in the following excerpt from the memorandum:

The political importance of a community, to a considerable extent, gains strength or suffers detriment according to the position that the members of that community occupy in the services of the state. If, as is unfortunately the case with the Mohamedans, they are not adequately represented, they lose in prestige and influence which is their due. ${ }^{60}$

Furthermore, the deputationists also urged the need for the creation of a Muslim university, ${ }^{61}$ and hoped that "due consideration" would be given to the position they had occupied in the Indian subcontinent a little more than one hundred years before. ${ }^{62}$

It is worth noting that the drafters of the Simla address were careful not to direct any criticism at policy pursued by the British towards the Muslim community. In this respect, Matiur Rahman observed that in the memorandum a very temperate language was used by the deputationists in placing their grievances before the Viceroy. ${ }^{63}$

Meanwhile, the proposals that were put forward by the Muslim deputation to the Viceroy of India were elaborately discussed in private and official correspondence between the latter and the Secretary of State for India in London, Lord Morley, as well as other official circles. ${ }^{64}$ The result was that the Muslims of India, at last, managed to gain some favours from the British

\footnotetext{
${ }^{58}$ RAHMAN, M. From Consultation to Confrontation: A Study of the Muslim League in British Indian Politics: 1906 - 1912, p. 12.

${ }^{59}$ LOVETT, V. Nationalist Movement in India, p. 74.

60 Quoted in RAHMAN, M. From Consultation to Confrontation: A Study of the Muslim League in British Indian Politics: 1906 - 1912, p. 296.

${ }^{61}$ LOVETT, V. Nationalist Movement in India, p. 74.

62 WASTI, S. R. The Simla Deputation: 1906. In WASTI, S. R. (ed.). Muslim Struggle for Freedom in India, p. 88.

${ }^{63}$ RAHMAN, M. From Consultation to Confrontation: A Study of the Muslim League in British Indian Politics: 1906 - 1912, p. 14.

${ }^{64}$ WASTI, S. R. The Simla Deputation: 1906. In WASTI, S. R. (ed.). Muslim Struggle for Freedom in India, p. 89.
} 
government. In fact, Lord Minto's reply, though 'non-committal', was reassuring as well as "extremely sympathetic". ${ }^{65}$ His words were:

... I can only say to you that the Mahomedan Community may rest assured that their political rights and interests as a community will be safe-guarded in any administrative organization with which I am concerned...66

Lord Minto complimented the leaders of the Aligarh movement for the efforts they had made and their achievements in advancing their community. In addition, the Viceroy also expressed his gratitude to the Muslims of the newlyborn Muslim majority province, namely East Bengal and Assam, for the moderation and self-restraint they had shown in the face of the anti-partition agitation. $^{67}$

Furthermore, the Viceroy declared that although British ideas had to prevail, there was no reason why they should not listen to and accept other political proposals. Then he said:

You justly claim that your position should be estimated not merely on your numerical strength, but in respect of the political importance of your community and the service it has rendered to the Empire. I am in accordance with you. ${ }^{68}$

The deputationists, comforted by the positive reply of the Viceroy, breathed a sigh of relief. Their contentment was described by A. Read and D. Fisher, who stated that in the afternoon of that day, in the grounds of the Viceregal Lodge, the deputationists expressed their satisfaction to Lady Minto by saying: "Now we feel the viceroy is our friend". 69

Hence, after receiving the "blessings" of Lord Minto, the Indian Muslims decided that the time was ripe for the founding of a political party. The initiative was taken by Sir Khwaja Salimullah Bahadur ${ }^{70}$, the Nawab of Dacca, who was

\footnotetext{
${ }^{65}$ Ibid.

${ }^{66}$ Quoted in, RAHMAN, M. From Consultation to Confrontation: A Study of the Muslim League in British Indian Politics: 1906 - 1912, p. 302.

${ }^{67}$ READ, A., FISHER, D. The Proudest Day: India's Long Road to Independence, p. 92.

${ }^{68}$ LOVETT, V. Nationalist Movement in India, pp. 74-75.

69 READ, A., FISHER, D. The Proudest Day: India's Long Road to Independence, p. 93.

${ }^{70}$ Khwaja Salimullah Bahadur (1871 - 1915) was a local Muslim leader, historically known as Nawab Salimullah.
} 
not a member of the Simla Deputation. ${ }^{71}$ This Muslim leader called for the annual meeting of the Muhammedan Educational Conference, under the presidency of Nawab Viqar-ul-Mulk ${ }^{72}$, to be held in his hometown, Dacca, by the end of December 1906.

Throughout the Dacca session of the Muhammedan Educational Conference, Nawab Salimullah circulated the blueprint for the establishment of the first allIndia Muslim political party, which, ultimately, received wide support from those who were present. ${ }^{73}$ Here, it is important to note that Nawab Mohsin-ulMulk had initially opposed the idea of using the Muhammedan Educational Conference for political ends; however, some sort of compromise was soon reached with the other leaders attending the conference. ${ }^{74}$ Therefore, it was in the wake of such a crucial meeting, that is, on 30 December 1906, that a Muslim political party, called the All India Muslim League, saw the light of day, and Nawab Mohsin-ul-Mulk and Nawab Viqar-ul-Mulk were appointed as its joint secretaries. $^{75}$

It should be emphasized that in spite of taking the initiative, the Nawab of Dacca was by no means the only person behind the formation of the first Muslim political movement. In this regard, Vinod K. Saxena pointed out that the members of the Simla Deputation, and particularly its leader, the Agha Khan, played a key role in this direction. ${ }^{76}$ This was corroborated by Khursheed K. Aziz, who cited the Agha Khan as saying on the eve of the creation of the All-India Muslim League that:

...the only hope lay in the establishment of a Muslim political body to secure 'independent political recognition from the British Government as a nation within a nation' ${ }^{77}$

On the other hand, Vinod K. Saxena mentioned that the Agha Khan told the deputationists that the Muslim achievement of 1906, namely the obtaining of

\footnotetext{
71 Tariq Hasan asserted that Nawab Salimullah had earlier been marginalized by the "Aligarh Group". HASAN, T. The Aligarh Movement and the Making of the Indian Muslim Mind: 1857 - 2002, p. 138.

72 Nawab Viqar-ul-Mulk (1841 - 1917) was another of the late Sir Sayyid Ahmad Khan's close companions.

${ }^{73}$ SAXENA, V. K. Muslims and the Indian National Congress: 1885 - 1924, p. 101.

${ }^{74}$ HASAN, T. The Aligarh Movement and the Making of the Indian Muslim Mind: 1857

- 2002, p. 138.

${ }^{75}$ Ibid., p. 139.

${ }^{76}$ SAXENA, V. K. Muslims and the Indian National Congress: 1885 - 1924, p. 99.

77 AZIZ, K. K. The Making of Pakistan: A Study in Nationalism, p. 29.
} 
separate electoral recognition from Lord Minto, should be complemented by political recognition in order "to make that separate representation effective". ${ }^{78}$

Apart from that, the aims and objectives of the All-India Muslim League centred on the following three major points: first, the promotion of the feeling of loyalty among the Muslims of India towards the British rulers; second, the protection and the advancement of the interests and political rights of the Muslim community; third, the prevention of the rise of any feeling of hatred among Indian Muslims towards the other communities inhabiting the Indian subcontinent. ${ }^{79}$

Meanwhile, in London, the creation of the first widely-based Muslim party triggered mixed reactions from the British press. There were those who adopted a positive stance on this move and those who frowned upon it. The Complementary Review, a monthly newspaper, hailed the emergence of this political organization and, while analysing its aims and objectives, contrasted its constitutional and loyal approach with the Indian National Congress's agitational methods. ${ }^{80}$ Besides, commenting on the latest development on the Indian political scene, the same paper stated that:

The Rubicon has been crossed, the Muslims of India have forsaken the shades of retirement for the political arena; henceforth a new factor in Indian politics has to be reckoned with. ${ }^{81}$

Interestingly, most of the British press that adopted a positive attitude towards the Simla Deputation, and its subsequent formation of the All-India Muslim League, did it out of disagreement with the Congress's "overreaction" to the partition of Bengal - which aimed at hurting the British economy through the swadeshi campaign. ${ }^{82}$ The Western Press, for instance, which was in favour of the Muslim move to secure an independent political recognition, stated in one of its columns:

\footnotetext{
${ }^{78}$ SAXENA, V. K. Muslims and the Indian National Congress: 1885 - 1924, p. 99.

${ }^{79}$ SYMONDS, R. The Making of Pakistan, p. 41.

${ }^{80}$ SAXENA, V. K. Muslims and the Indian National Congress: 1885 - 1924, p. 105.

${ }^{81}$ Quoted in ibid., p. 106.

82 The Hindu anti-partition furore took a new turn by giving birth to a boycott movement, usually referred to as the Swadeshi movement. The term swadeshi literally means "one's own country", and therefore this movement, which was declared on 7 August 1905, aimed to boycott British goods and use Indian-made goods instead, in order to force the British colonial government to revoke the partition of Bengal, see WASTI, S. R. Partition of Bengal and its Immediate Effects. In WASTI, S. R. (ed.). Muslim Struggle for Freedom in India, p. 70.
} 
Muslims Venture into Politics in India: A British Ploy or an Instinctive Reaction

The last agitation in Bengal had aroused the feeling of indignation among the Muslims and yesterday's deputation signifies the fact that the government should better not give much attention to the hue and cry of those who as a result of their glib tongue and their egoism have convinced themselves of being a nation. ${ }^{83}$

Nevertheless, there were many other British papers to whom the birth of the first permanent Muslim political organization represented a serious danger, threatening the stability of the British Empire in South Asia. One of these was The Times on 2 January 1907, which expressed its misgivings about the future of the state of affairs in British India. ${ }^{84}$ Another paper, the Spectator, a conservative weekly, revealed on 5 January 1907, that they did not like that feeling among the Indian Muslims that they had to "organize in a camp by themselves". 85

Moreover, in a threatening tone, the Morning Post, a conservative daily, warned the All-India Muslim League that its activities must be "entirely defensive and protective", and that in the event it departed from its aims and objectives and "becomes frankly antagonistic to the Hindu or any other race", it would, immediately, incur "the most drastic intervention of the British rulers". 86 Here, it is worth recalling the fact that the creation of the Indian National Congress back in 1885 was not subjected to such criticism by the British press as was the All-India Muslim League.

In the meantime, one of the moot points often discussed among scholars concerned with the political history of the Indian Muslims was the one related to the origin of the All-India Muslim League. Actually, the question of whether the creation of the All-India Muslim League had been genuinely a Muslim idea, or simply a stratagem devised by the colonial government in order to disunite, and hence weaken, the population of the subcontinent, has divided scholars into two camps: those who believed that it was a definitely Muslim project, and those who said that it was a Britain-made political party.

Indeed, many scholars assume that the creation of the All-India Muslim League was contrived by the British authorities in India as well as in Britain in order to quash, or rather, nip in the bud, any attempt at a united Hindu-Muslim anti-imperialist action, that might result from the mounting feeling of

${ }^{83}$ Quoted in HASAN, T. The Aligarh Movement and the Making of the Indian Muslim Mind: 1857 - 2002, p. 132.

${ }^{84}$ AZIZ, K. K. Britain and Pakistan: A Study of British Attitude towards the East Pakistan Crisis of 1971, p. 12.

${ }^{85}$ Ibid.

${ }^{86}$ RAHMAN, M. From Consultation to Confrontation: A Study of the Muslim League in British Indian Politics: 1906 - 1912, p. 42. 
discontentment among the inhabitants of India because of the exploitative policies of the British. In this respect, H. D. Sharma cited a Hindu contemporary, B. R. Ambedkar (1891 - 1956), as contending that the switch in the British government's policy towards the Muslims of India, who, only several decades before had been Britain's bêtes noires, was intended to "wean away the Congress and create a breach and disunity between the Hindus and the Musalmans". ${ }^{87}$ In this sense, B. R. Ambedkar argued, the British were "mightily successful", given the fact that the late Sir Sayyid Ahmad Khan had already "poisoned" the mind of his co-religionists and, additionally, their religion - i.e. Islam - had an "inbuilt antagonism" against the believers of other creeds. ${ }^{88}$

Put another way, the willingness to give the Muslim community favourable treatment in the administration of the country was interpreted by many scholars as a part of the strategy of political counterpoise employed by the British colonial government in order to keep its paramountcy. ${ }^{89}$ Besides, Lord Minto's positive reply to the Muslims of India represented an official recognition of the existence of two separate nations in India, Hindu and Muslim, which had conflicting interests and outlooks. ${ }^{90}$

As a reaction, the Hindu Congressmen, while attempting to minimize the Muslim-Hindu differences, blamed the British officials for driving a wedge between the "brothers", who were both being exploited by the rulers. K. K. Aziz summed up their opinion in the following lines:

\begin{abstract}
All Indians were like brothers unto each other. There were no differences among them. In particular Hindus and Muslims were good to each other and had only occasional, minor tiffs. But a rift had been created between them. The British were the villains of the piece. To achieve their selfish, sordid end they divided the Indians into religious groups and sided sometimes with the one and sometimes with the other. This helped to prolong the tenure of British rule and kept the Indians quarrelling among themselves rather than fighting for independence. ${ }^{91}$
\end{abstract}

In addition to that, Bipan Chandra et al. declared that the British managed to achieve their divisive objective with the help of some Muslim leaders, and

87 SHARMA, H. D. (ed.). 100 Best Pre-Independence Speeches: 1870 - 1947, pp. $72-73$.

${ }^{88}$ Ibid.

${ }^{89}$ DESAI, A. R. Social Background of Indian Nationalism, p. 362.

${ }^{90}$ SHARMA, H. D. (ed.). 100 Best Pre-Independence Speeches: 1870 - 1947, p. 78.

${ }^{91}$ AZIZ, K. K. The Making of Pakistan: A Study in Nationalism, pp. 92-93. 
particularly Sir Sayyid Ahmad Khan, to whom the rise of Muslim communalism in the Indian subcontinent was attributed. ${ }^{92}$

In retrospect, the British strategy of setting communities against each other for a better administration of the natives had been a recurrent subject in the private and official correspondence of early British officials in the subcontinent. M. A. Karandikar argued that as far back as 1821, a British officer made it clear in the Asiatic Journal - published in Britain - that divide et impera, or divide and rule, should be the motto of the British administration in India. ${ }^{93}$ Sharing the same opinion, another officer, Lieutenant John Coke, said unreservedly that:

Our endeavour should be to uphold in full force the separation which exists between the different religions and races; not to endeavour to amalgamate them. Divide et impera should be the principle of the Indian Government. $^{94}$

Meanwhile, Akshayakumar R. Desai affirmed that some high level officers made reference to the policy of separating the different communities inhabiting the subcontinent in the name of their religious beliefs for the sake of perpetuating British rule there. One of these was Lord Elphinstone (1807 1860), governor of Bombay from 1853 to 1860, who declared that "divide et impera was the old Roman motto, and it should be ours". 95

In the early twentieth-century Indian context, no one can deny the fact that the swift shift in official British policy towards the Muslim community and the positive response to the latter's political demands had, in effect, heightened the tension in the already strained relations between the Hindu and Muslim communities. This could be reflected in the hostile statements that filled the columns of the Hindu press, and particularly, the Bengalee, the mouthpiece of the Indian National Congress, which referred to the All-India Muslim League as "Nawab Salimullah's latest fad".96

Apart from that, Syed Nezar Ahmad has pointed out that there was evidence that by adopting a positive attitude towards the Muslims of India, the British colonial government aimed at "promoting the notion of exclusivism" among them, a measure that would forestall any attempt at joining hands with the Hindus in order to make common cause. This could be seen in the fact that, as

${ }^{92}$ CHANDRA, B., TRIPATHI, A., DE, B. Freedom Struggle, pp. 102-103.

${ }^{93}$ KARANDIKAR, M. A. Islam in India's Transition to Modernity, p. 154.

${ }^{94}$ Ibid.

${ }^{95}$ DESAI, A. R. Social Background of Indian Nationalism, p. 362.

96 SAXENA, V. K. Muslims and the Indian National Congress: 1885 - 1924, pp. 106-107. 
far back as the 1870s, British officials began encouraging Indian Muslims to organize themselves as Muslims and to seek concessions as a separate community. ${ }^{97}$ Naturally, this would bring about communal friction with the Hindus. In other words, the British wanted to widen the rift between the Muslim and Hindu communities and favoured the Indian Muslims so that they - the Muslims - would oppose every Hindu "advance towards self-government". 98

When looked at objectively, the British policy towards the Muslim community had undergone, in a strange way, a U-turn by the last quarter of the nineteenth century. As a matter of fact, whereas in the wake of the bloody events of 1857 they were looked down upon and considered as a "bunch" of "criminals", almost a couple of decades later they became, if not the protégés, then at least the friends of the rulers. Even Lord Mayo (1822 - 1872), who had ruled India between 1869 and 1872, once confessed that he regretted past British policies towards the Muslim community. ${ }^{99}$ In this respect, the British scholar Francis Robinson, quoted at length below, has described the new British attitude towards this community thus:

... when a group of north Indian Muslims, led by the gifted and energetic Sayyid Ahmad Khan, strove to build bridges between Islam and modern science and between Indian Muslims and the colonial state, they were looked upon with approval. When this group went on to found MAO College Aligarh in 1877 and the All-India Muhammadan Educational Conference in 1886 to carry the process forward, it received moral and material support from government. When this group, known as the Aligarh movement, made a point of not supporting the Indian National Congress, $\ldots$ the British were not displeased. Moreover, when representatives of this movement went in deputation to the Viceroy in 1906 to ask for special representation for Muslims and recognition of their 'political importance' in the new legislative councils..., they were received with sympathy. ${ }^{100}$

97 AHMAD, S. N. Origins of Muslim Consciousness in India: A World-System Perspective, p. 82.

${ }^{98}$ AZIZ, K. K. The Making of Pakistan: A Study in Nationalism, p. 93.

${ }^{99}$ Syed Nezar Ahmad quotes Lord Mayo as saying: "We have not only failed to attract the sympathies and confidence of a large and important section of the community but we have reason to fear that we have caused positive disaffection." AHMAD, S. N. Origins of Muslim Consciousness in India: A World-System Perspective, pp. 82-83.

${ }^{100}$ Robinson, F. The British Empire and Muslim Identity in South Asia. In Transactions of the Royal Historical Society, Vol. 8, p. 277. 
This fact has led many scholars to raise endless questions about the rationale behind such a swift shift in policy. Moreover, even Lord Curzon's cajoling statements to the Muslim community during his tour in the province of Bengal in 1904 - to gain their support for his partition plan-left room for much speculation among these scholars about the reason behind such an "unnaturally" caring and affective attitude towards the Bengali Muslims. Some historians, like Jim Masselos, believe that Lord Curzon, who went to the extent of providing inducements to the local leaders, wanted to woo support from the Muslim community for it to serve as a counterpoise to anti-partition Hindu agitation ${ }^{101}$ thus confirming Khursheed K. Aziz's statement above.

Furthermore, Bipan Chandra et al. went a step further in claiming that the partition of Bengal was in itself part of a scheme to prop up Muslim communalists as a counterweight to the Congress and the nationalist movement, ${ }^{102}$ while Vinod K. Saxena argued that the primary objective for Lord Curzon's partition scheme was to "undermine the solidarity of the Bengalispeaking people and to drive a wedge between the Hindus and the Musalmans". 103

Regarding the All-India Muslim League, many Hindu Congressmen argued that it came into being as a result of governmental machinations and that there were some British officials who "pulled strings from behind the scenes" to indirectly exhort the Muslims of India to politicize their cause. ${ }^{104}$ The Amrita Bazar Patrika, a Hindu paper, referred to the whole story as a "got-up affair fully engineered by interested officials". ${ }^{105}$ To back up their view, the supporters of this argument relied on Lady Mary Minto's diary, in which she made reference to a statement made by a British official who attended the Simla meeting:

A very big thing has happened today. A work of statesmanship that will affect India and Indian history for many a long year. It is nothing less than the pulling back of sixty-two millions of people from joining the ranks of seditious opposition. ${ }^{106}$

${ }^{101}$ MASSELOS, J. Indian Nationalism: An History, p. 133.

102 BIPAN, C., MRIDULA, M., ADITYA, M., PANIKKAR, K. N., SUCHETA, M. India's Struggle for Immediate Independence, p. 125.

${ }^{103}$ SAXENA, V. K. Muslims and the Indian National Congress: 1885 - 1924, p. 115.

${ }^{104}$ MASSELOS, Jim. Indian Nationalism: An History, p. 135.

${ }^{105}$ WASTI, S. R. The Simla Deputation: 1906. In WASTI, S. R. (ed.). Muslim Struggle for Freedom in India, p. 91.

106 Quoted in SHARMA, H. D. (ed.). 100 Best Pre-Independence Speeches: $1870-$ 1947, p. 77. 
Yet, according to H. D. Sharma, the idea that the deputationists, composed of the most influential and respectable members of the Muslim community, had been so easily tricked by the British was difficult to believe. Hence, H. D. Sharma concluded, the "Aligarh Group" were "willing to be commanded". 107

Indeed, according to Matiur Rahman, the critics of the Simla Deputation often referred to it as a "command performance", which was manipulated from the colonial headquarters at Simla as a consequence of a "conspiracy between the British and the Muslims". ${ }^{108}$ Here, it is worth noting that the appellation "command performance" was coined by Maulana Mohammad Ali (1878 1931), one of the few Indian Muslims who remained loyal to the Indian National Congress after the formation of the All-India Muslim League. ${ }^{109}$

In the meantime, at the other end of the scale, the above allegation has been vehemently condemned and refuted by many Muslim scholars. Syed R. Wasti, for instance, contended that the very idea that the Simla Deputation was "engineered" by the British government in order to serve as a "counterpoise to the Congress aims" was but a distortion of facts. In this regard, he wrote:

To subscribe to such opinions is to distort history and to underrate both Muslim political aspirations and the integrity and intellectual capability of Muslim leadership. ${ }^{110}$

Syed R. Wasti further added that when the All-India Muslim League was founded, it did not receive "the degree of Government patronage" that its 'pseudo-national' Hindu predecessor - the Indian National Congress - had received from the colonial authorities. ${ }^{111}$

On the other hand, Khursheed K. Aziz pointed out that there was no evidence substantiating the claim that the Muslims' demand for separate electorates had been imposed upon them against their will. ${ }^{112}$ He further argued

\footnotetext{
107 Ibid.

108 RAHMAN, M. From Consultation to Confrontation: A Study of the Muslim League in British Indian Politics: 1906 - 1912, p. 15.

109 LIMAYE, M. Indian National Movement: Its Ideological and Socio-Economic Dimensions, p. 196.

${ }^{110}$ WASTI, S. R. The Simla Deputation: 1906. In WASTI, S. R. (ed.). Muslim Struggle for Freedom in India, p. 93.

111 Some of the founders of the Indian National Congress back in 1885 were former British officials, and notable among them was Allen Octave Hume. Moreover, even the then Viceroy, Lord Dufferin, who had in some ways encouraged the formation of this party, gave it his blessing, see WASTI, S. R. Lord Minto and the Indian Nationalist Movement: 1905 - 1910, p. 12.

112 AZIZ, K. K. The Making of Pakistan: A Study in Nationalism, p. 93.
} 
that because of their status as a minority in the subcontinent, and fearing the Hindu majority, the Indian Muslims had to resort to the British, since it always heartens the rulers to find a section of the subjugated people on their side and not on the side of the refractory subjects, while the minorities always find it wise to maintain good relations with the ruling power. Therefore, the "Muslim was thrown into the arms of the British by circumstances, and the Hindus did not like it and attributed it to British devilry...".113

Moreover, Khursheed K. Aziz observed that the Hindu-Muslim antagonism was essentially a clash of two separate and incompatible civilizations, so this incompatibility could by no means be attributed to the British. Probably some British officials took advantage of such Muslim-Hindu divergences, for if they had not, they "would have been more than human". ${ }^{114}$ Hence, the Indians had long been divided and let the British rule them.

This argument was also championed by Matiur Rahman who pointed out that long before the establishment of the All-India Muslim League, there had been a clamour, albeit at a local level, for the establishment of a central Muslim organization as a result of the "social exclusiveness" of the Muslim and Hindu communities. Furthermore, this Muslim scholar ascribed the contention that this Muslim political organization was the "handmaiden" of the colonial government to the deliberate and politically-motivated errors made by certain writers. ${ }^{115}$

As part of his efforts to refute the allegation that the colonial administration had any involvement in organizing the Muslim deputation, Matiur Rahman went further in delving deeply into the personal papers left by some Muslim leaders and British officials. Thus, he realized that when Nawab Mohsin-ulMulk, on behalf of the deputationists, requested Lord Minto, via Archbold, to receive a Muslim deputation, the Viceroy took time to reply. This was substantiated by a letter that Lord Minto sent on 8 August 1906 to Lord Morley, the then Secretary of State for India in London, in which he disclosed the fact that he was at the time "undecided whether to receive the deputation or not". 116

Along the same line of thought, Syed R. Wasti revealed the fact that Lord Minto did not have the slightest idea about what the Muslim deputationists intended to ask of him. ${ }^{117}$ Lending support to this statement was a letter that the Viceroy sent to Lord Morley on 10 September 1906, in which he stated:

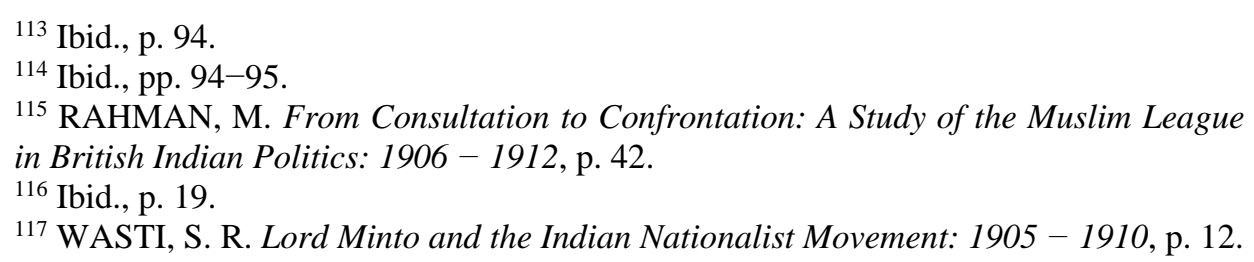


I am to receive the Mohammedan deputation on the 1st of October, and if I can succeed in saying the right thing it may have a great effect on the present position. My answer must of course depend considerably on the points put forward, but, from what I hear, the Address is likely to be moderate in tone. ${ }^{118}$

Syed R. Wasti then asserted that both the Viceroy and the Secretary of State for India were racking their brains, throughout their correspondence, trying to find possible answers to a memorandum "about the contents of which they had no knowledge as yet". 119

In addition to all that, Syed R. Wasti, leaving no stone unturned, looked into the financial aspect of the Simla Deputation. This led him to go through the documents of the All-India Muslim League, archived at the University of Karachi, Pakistan. From such documents, Syed R. Wasti managed to lay hands on a file entitled 'King, King and Co'. After thorough examination of the file, he came up with further evidence - which he published in an article during the 1970s, entitled 'New Facts about the Simla Deputation: 1st October 1906' supporting his earlier argument that the British had no hand in the formation of the Simla Deputation. In fact, this proof indicated that Nawab Mohsin-ul-Mulk had himself borrowed money from 'King, King and Co', which was a lending company, in order to cover the expenses of the deputation. Besides that, Mohsin-ul-Mulk took out the loan at $7 \%$ interest and on his personal surety. ${ }^{120}$

This leads one to the conclusion that if the British officials were, indeed behind the Muslims' demand for separate electorates - which was a steppingstone towards the formation of the first permanent widely-based Muslim political party - could they not, at least, have defrayed the expenses incurred by the deputationists since, as some scholars allege, the latter were rendering a service to the rulers?

\section{REFERENCES}

ABBASI, Muhammad Yusuf. The Genesis of Muslim Fundamentalism in British India. New Delhi: Eastern Book Corporation, 1987.

\footnotetext{
${ }^{118}$ Quoted in ibid., p. 68.

${ }^{119}$ Ibid., p. 69.

${ }^{120}$ WASTI, S. R. New Facts about the Simla Deputation: 1st October 1906. In WASTI, S. R. (ed.). Muslim Struggle for Freedom in India, pp. 110-111.
} 
AZIZ Khursheed K. Britain and Pakistan: A Study of British Attitude towards the East Pakistan Crisis of 1971. Islamabad: University of Islamabad Press, 1974.

AZIZ Khursheed K. The Making of Pakistan: A Study in Nationalism. London: Chattos \& Windus, 1967.

BELMEKKI, Belkacem. Shah Walyi Allah Delhavi's Attempts at Religious Revivalism in South Asia. In Anthropos: International Review of Anthropology and Linguistics, Anthropos Institut, Germany, 2014, Vol. 109, No. 2, pp. 621 - 625. https://doi.org/10.5771/0257-9774-2014-2-621

BIPAN, Chandra, MRIDULA, Mukherjee, ADITYA, Mukherjee, PANIKKAR, K. N., SUCHETA, Mahajan. India's Struggle for Immediate Independence. New Delhi: Penguin Books, 1989.

BIPAN, Chandra, TRIPATHI, Amales, DE, Barun. Freedom Struggle. New Delhi: National Book Trust, 1983.

DESAI, Akshayakumar R. Social Background of Indian Nationalism. Bombay: Popular Book Depot, 1959.

ROBINSON, Francis. The British Empire and Muslim Identity in South Asia. In Transactions of the Royal Historical Society, 1998, Vol. 8, pp. 271-289. https://doi.org/10.2307/3679298

MALIK, Hafeez. Sir Sayyid Ahmad Khan and Muslim Modernization in India and Pakistan. New York: Columbia University Press, 1980.

HASAN, Tariq. The Aligarh Movement and the Making of the Indian Muslim Mind: 1857 - 2002. New Delhi: Rupa \& Co., 2006.

HORNE, E. A. The Political System of British India: With Special Reference to the Recent Constitutional Changes. Oxford: Clarendon Press, 1922.

SHAMEEM, Kadri H. Creation of Pakistan. Lahore: Wajidalis, 1982.

KARANDIKAR, M. A. Islam in India's Transition to Modernity. Karachi: Eastern Publishers, 1968.

HANS, Kohn. A History of Nationalism in the East, The Idea of Nationalism: Its Origin and Background. New York: Macmillan Publishers, 1944.

LIMAYE, Madhu. Indian National Movement: Its Ideological and SocioEconomic Dimensions. India: Sangam Books, 1989.

VERNEY, Lovett. Nationalist Movement in India. India: Akashdeep Publishing House, 1988.

MASSELOS, Jim. Indian Nationalism: An History. New Delhi: Sterling Publishers Private Limited, 1996.

Mehrotra S. R. India and the Commonwealth: 1885 - 1929. London: George Allen and Unwin Ltd., 1965.

SHAN, Muhammad (ed.). The Aligarh Movement: Basic Documents: 1864 1898. Meerut: Meenakshi Prakashan, 1978. 
RAHMAN, Matiur. From Consultation to Confrontation: A Study of the Muslim League in British Indian Politics: 1906 - 1912. London: Luzac \& Company Ltd., 1970.

READ, Anthony and FISHER, David. The Proudest Day: India's Long Road to Independence. London: Pimlico, 1998.

VINOD, Saxena Kumar. Muslims and the Indian National Congress: 1885 1924. Delhi: Discovery Publishing House, 1985.

SHARMA, H. D. (ed.). 100 Best Pre-Independence Speeches: 1870 - 1947. New Delhi: HarperCollins Publishers, 1998.

SPEAR, Percival. A History of India: From the Sixteenth Century to the Twentieth Century. Middlesex: Penguin Books, 1990.

AHMAD, Syed Nezar. Origins of Muslim Consciousness in India: A Worldsystem Perspective. New York: Greenwood Press, 1991.

SYMONDS, Richard. The Making of Pakistan. London: Faber and Faber, 1949.

WASTI, Syed Razi. Lord Minto and the Indian Nationalist Movement: 1905 1910. Oxford: Clarendon Press, 1964.

WASTI, Syed Razi. Partition of Bengal and its Immediate Effects. In WASTI, Syed Razi (ed.). Muslim Struggle for Freedom in India. Delhi: Renaissance Publishing House, 1993. 